\title{
PENGARUH GAYA KEPEMIMPINAN TERHADAP MOTIVASI DAN KEPUASAN KERJA (Studi pada Kasubag di Lingkungan Universitas Brawijaya Malang)
}

\author{
Jarot Ilhami Wijaya, Djamhur Hamid, Hamidah Nayati Utami \\ Fakultas Ilmu Administrasi Universitas Brawijaya Malang \\ Email : zhabier@ub.ac.id
}

\begin{abstract}
In the modern organization, leadership will influence the behavior of employees in performing their duties. Job satisfaction change efforts require the participation of the leadership and all employees, it would also be achieved if there is the willingness and ability of each individual employee. This study aimed (1) to identify and explain the influence of leadership on employee motivation, (2) to identify and explain the influence, leadership on work motivation on employee job satisfaction. The research was conducted at Brawijaya University with 95 employees sampled. The statistical methods used to test the hypothesis is path analysis. Improved employee motivation preceded by the proper application of good leadership on task behavior and relationship. High job satisfaction necessary for excellent service or high quality services can be held. The data of this study to get some important conclusions that leadership is very important for employees in an effort to improve employee job satisfaction both directly and indirectly.
\end{abstract}

Keywords: leadership, work motivation, job satisfaction

\section{ABSTRAK}

Di dalam organisasi modern, kepemimpinan akan mempengaruhi perilaku kerja karyawan dalam menjalankan tugas. Usaha perubahan kepuasan kerja membutuhkan partisipasi dari pimpinan dan semua karyawan, itu akan tercapai bila juga ada kemauan dan kemampuan dari masing-masing individu karyawan. Penelitian ini bertujuan (1) untuk mengetahui dan menjelaskan pengaruh kepemimpinan terhadap motivasi kerja karyawan; (2) untuk mengetahui dan menjelaskan pengaruh, kepemimpinan terhadap motivasi kerja terhadap kepuasan kerja karyawan. Penelitian ini dilakukan di Universitas Brawijaya dengan sampel berjumlah 95 karyawan kasubag. Metode statistik yang digunakan untuk menguji hipotesis adalah analisis jalur. Peningkatan motivasi karyawan didahului oleh penerapan kepemimpinan yang tepat baik pada perilaku tugas dan hubungan. Kepuasan kerja tinggi dibutuhkam agar pelayanan prima atau pelayanan yang bermutu tinggi dapat terselenggara. Data penelitian ini mendapatkan beberapa kesimpulan penting bahwa kepemipinan sangat penting bagi karyawan dalam upaya meningkatkan kepuasan kerja karyawan baik secara langsung maupun tidak langsung

Kata kunci: Kepemimpinan, Motivasi kerja, kepuasa kerja 


\section{PENDAHULUAN}

Sumber daya manusia memegang peranan yang sangat penting untuk mencapai keberhasilan dan tujuan dari suatu organisasi, sumber daya manusia ini menunjang organisasi dengan karya, bakat, dan dorongan yang dimilikinya. Perkembangan Manajemen Sumber Daya Manusia saat ini didorong oleh kemajuan peradaban, pendidikan, ilmu pengetahuan, dan tuntutan daya saing produksi barang dan jasa yang dihasilkan. Perkembangan ini dimulai sejak adanya kerjasama dan pembagian kerja diantara dua orang atau lebih. Pengelolaan Sumber Daya ini sangat penting untuk mencapai tujuan organisasi melalui manajemen yang baik akan memudahkan terwujudnya tujuan perusahaan, karyawan, dan masyarakat.

Pentingnya peran kepemimpinan dalam sebuah organisasi menjadi fokus yang menarik perhatian para peneliti bidang perilaku keorganisasian. Bass (1990) menyatakan bahwa kualitas gaya dari pemimpin sering kali dianggap sebagai faktor penting yang menentukan keberhasilan atau kegagalan organisasi. Schein (1992) juga mengatakan bahwa pimpinan mempunyai pengaruh besar terhadap keberhasilan organisasi. Porter (1996) dalam Sunarsih (2001) menyatakan bahwa kepemimpinan merupakan suatu unsur kunci dalam keefektifan organisasi.

$\begin{array}{clr}\text { Selain } & \text { gaya kepemimpinan yang } \\ \text { ditunjukkan } & \text { seorang pemimpin } & \text { untuk }\end{array}$ memberikan arahan kepada bawahan, yang harus dipahami oleh seorang pemimpin bahwa mengatur karyawan adalah hal yang sulit dan kompleks, karena mereka mempunyai pikiran. Perasaan, status, keinginan dan latar belakang yang heterogen yang dibawa ke dalam organisasi. Karyawan tidak dapat diatur dan dikuasai sepenunhnya seperti mengatur mesin, modal atau gedung, karyawan merupakan assets yang sangat berharga yang dimiliki oleh perusahan. Tujuan tidak mungkin terwujud tanpa peran aktif karyawan meskipun alat-alat yang dimiliki perusahaan begitu canggihnya. Alat-alat canggih yang dimiliki perusahaan tidak ada manfatnya bagi perusahaan, jika peran aktif karyawan tidak diikutsertakan. Sehingga untuk bisa memadukan antara kepentingan perusahaan dan kebutuhan karyawan seorang pemimpin harus mengintegrasikan kedua hal tersebut, salah satunya dengan pemberian motivasi.

Dengan motivasi ini pemimpin dapat mendorong atau menggerakan potensi bawahan, agar mau bekerja sama secara produktif berhasil dan mewujudkan tujuan yang telah ditentukan, perusahaan bukan saja mengharapkan karyawan mampu, cakap dan terampil, tetapi yang terpenting mereka mau bekerja giat dan berkeinginan untuk mencapai hasil kerja yang maksimal. Kemampuan dan kecakapan karyawan tidak ada artinya bagi perusahaan jika mereka tidak mau bekerja dengan giat. Kecanggihan peralatan yang didukung Sumber Daya Manusia yang terampil dan berkualitas akan dapat memberikan manfaat yang besar bagi perusahaan sesuai dengan tuntutan perkembangan keadaan. Gaya kepemimpinan seorang pemimpin dan motivasi yang diberikan oleh pemimpin kepada bawahannya sangat berpengaruh terhadap kinerja bawahan dalam hal ini adalah karyawan. Kinerja yang baik dari bawahan dapat diperoleh dengan gaya kepemimpian dan motivasi pemimpin yang baik pula. Kinerja merupakan cara yang diperoleh dari kedua hal tersebut dalam menyelesaikan tugas atau pekerjaan seseorang dan suatu hal penting dalam upaya perusahaan untuk mencapai tujuan perusahaan.

Menurut Keith Davis dan John W Newstrom (2000), dalam bukunya Perilaku Dalam Organisasi, kepuasan kerja adalah seperangkat perasaan pegawai tentang menyenangkan atau tidaknya pekerjaan mereka. Ada perbedaan yang penting antara perasaan ini dengan dua unsur lainnya dari sikap pegawai. Kepuasan kerja adalah perasaan senang atau tidak senang yang relative, yang berbeda dari pemikiran objektif dan keinginan perilaku. Ketiga bagian sikap itu membantu para manajer memahami reaksi pegawai terhadap pekerjaan mereka dan memperkirakan dampaknya pada perilaku di masa datang. Apabila pegawai bergabung dalam suatu organisasi, ia membawa serta seperangkat keinginan, kebutuhan, hasrat,dan pengalaman masa lalu yang menyatu membentuk harapan kerja. Kepuasan kerja menunjukkan kesesuaian antara harapan seseorang yang timbul dan imbalan yang disediakan pekerjaan. Jadi kepuasan kerja juga berkaitan erat dengan teori keadilan, perjanjian 
psikologis, dan motivasi. Kepuasan kerja umumnya mengacu pada sikap seorang pegawai. Kepuasan kerja juga dapat mengacu pada tingkat sikap yang umum di dalam suatu kelompok. Kepuasan kerja memiliki banyak dimensi. Ia dapat mewakili sikap secara menyeluruh, atau mengacu pada bagian pekerjaan seseorang. Sebagai sekumpulan perasaan, kepuasan kerja bersifat dinamik. Kepuasan kerja adalah bagian dari kepuasan hidup. Sifat lingkungan seseorang di luar pekerjaan mempengaruhi perasaan di dalam pekerjaan. Demikian juga halnya, karena pekerjaan merupakan bagian penting kehidupan, kepuasan kerja mempengaruhi kepuasan hidup seseorang. Hasilnya, terdapat dampak bolak balik yang terjadi antara kepuasan kerja dan kepuasan hidup.

Kepuasan kerja itu sendiri akan dapat tercipta salah satunya dengan adanya hubungan timbal balik yang positif antara pimpinan dan bawahan, sehingga bawahan akan merasa bahwa dirinya merupakan bagian yang terpenting dari organisasi kerja. Salah satu ciri yang membedakan antara organisasi atau perusahaan yang berhasil dengan organisasi yang tidak berhasil adalah kepemimpinan yang efektif.

Gaya kepemimpinan yang ada pada seorang pemimpin sangat berpengaruh dan berperan aktif dalam penciptaan iklim kerja. Para karyawan akan melaksanakan fungsi dan tugasnya dengan baik apabila tercermin pada proses penerimaan terhadap model atau gaya kepemimpinan yang diterapkan oleh pemimpin mereka. Secara tidak langsung suatu model atau gaya kepemimpinan yang diterapkan oleh seorang pemimpin sangat berpengaruh dominan karena hal tersebut dapat memberikan motivasi terhadap kepuasan kerja karyawan.

Berdasarkan yang telah diuraikan diatas, maka penulis tertarik untuk menjelaskan bagaimana pangaruh gaya kepemimpinan terhadap motivasi dan kepuasan kerja karyawan di Universitas Brawijaya Malang terutama di lingkungan Kasubag. Alasan peneliti mengambil sampel Kasubag karena hasil dari output kebijakan, berhubungan langsung dengan hasil pelayanan masyarakat yaitu karyawan/mahasiswa, Sehingga penulis memutuskan untuk melakukan penelitian dengan judul : "Pengaruh Gaya Kepemimpinan terhadap Motivasi dan Kepuasan Karyawan

\section{(Studi pada Kasubag di Lingkungan Universitas Brawijaya Malang)".}

\section{Rumusan Masalah}

Dalam thesis ini penulis ingin menjelaskan pengaruh gaya kepemimpinan terhadap motivasi dan kepuasan kerja di Universitas Brawijaya Malang. Berdasarkan latar belakang, maka penulis merumuskan masalah sebagai berikut:

1. Apakah Perilaku Tugas berpengaruh signifikan terhadap Motivasi ?

2. Apakah Perilaku Hubungan berpengaruh signifikan terhadap Motivasi ?

3. Apakah Perilaku Tugas berpengaruh signifikan terhadap Kepuasan Kerja ?

4. Apakah Perilaku Hubungan berpengaruh signifikan terhadap Kepuasan Kerja?

5. Apakah Motivasi berpengaruh signifikan terhadap Kepuasan Kerja ?

\section{Tujuan Penelitian}

Sesuai dengan perumusan masalah yang telah dikemukan sebelumnya, adapun tujuan mengadakan penelitian yang berjudul pengaruh gaya kepemimpinan terhadap motivasi dan kepuasan kerja di Universitas Brawijaya Malang, adalah:

1. Untuk menjelaskan pengaruh perilaku tugas terhadap motivasi.

2. Untuk menjelaskan pengaruh perilaku hubungan terhadap motivasi.

3. Untuk menjelaskan pengaruh perilaku tugas terhadap Kepuasan Kerja.

4. Untuk menjelaskan pengaruh perilaku hubungan terhadap kepuasan kerja.

5. Untuk menjelaskan pengaruh Motivasi terhadap Kepuasan Kerja.

\section{KAJIAN PUSTAKA \\ Perilaku Tugas}

Hersey dan Blanchard (2004:144) menjelaskan tentang perilaku tugas yaitu: Kadar upaya pemimpin mengorganisir dan menetapkan peranan anggota kelompok (pengikut) menjelaskan aktivitas setiap anggota serta kapan, dimana dan bagaimana cara menyelesaikannya, dicirikan dengan upaya untuk menetapkan pola organisasi, saluran komunikasi dan cara penyelesaian pekerjaan secara rinci dan jelas. Pendapat Hersey tersebut jelas bahwa perilaku tugas disini dapat menentukan apa yang 
dikerjakan, bagaimana cara mengerjakan, kapan dikerjakan dan untuk apa, biaya berapa, darimana, dengan siapa mengerjakan dan kesemuanya ini disampaikan kepada karyawan. Instrumen untuk mengukur perilaku tugas sangat penting diketahui, karena untuk mengetahui apakah perilaku tugas tersebut sudah sesuai dengan apa yang diharapkan sebelumnya atau belum, dengan kondisi tersebut maka manajemen akan dapat dengan cepat bertindak.

\section{Perilaku Hubungan}

Pengertian perilaku hubungan oleh Hersey dan Blanchard (2004:114) adalah suatu perilaku hubungan kepemimpinan dalam memberikan kesempatan kepada anggota untuk membicarakan segala sesuatunya yang berkenaan dengan tugas yang dilaksanakan bawahan. Sedang seberapa luas dan sempitnya kesempatan tersebut akan menyangkut gaya yang dilakukan pemimpin. Perilaku hubungan pada dasarnya merupakan kadar upaya kepemimpinan membina hubungan pribadi diantara hubungan pribadi mereka sendiri dan dengan para anggota kelompok mereka dengan jalan membuka lebar saluran komunikasi, menyediakan dukungan sosioemosional, psikologis dan kemudahan perilaku. Kelima dimensi pengukuran perilaku diatas oleh Hersey dan Blanchard yaitu Penyusunan dukungan, Mengkomunikasikan, Memudahkan interaksi, Aktif menyimak, Memberikan umpan balik

\section{Motivasi}

Motivasi merupakan masalah kompleks dalam organisasi, karena kebutuhan dan keinginan setiap anggota organisasi berbeda satu dengan yang lainnya. Hal ini berbeda karena setiap anggota suatu organisasi adalah unik secara biologis maupun psikologis, dan berkembang atas dasar proses belajar yang berbeda pula (Suprihanto dkk, 2003:41).

Motivasi menurut Gibson (2001:94) adalah konsep yang menguraikan tentang kekuatan-kekuatan yang ada dalam diri karyawan yang memulai mengarahkan perilaku. Sedangka motivasi menurut Robbins (2002:225) adalah kesediaan melakukan usaha tingkat tinggi guna mencapai sasaran organisasi, yang dikondisikan oleh kemampuan usaha tersebut memuaskan kebutuhan sejumlah individu. Motivasi adalah terpenuhinya kebutuhan-kebutuhan manusia yang dapat disusun dalam hirarki kebutuhan dari kebutuhan tertendah dampai yang tertinggi, yaitu kebutuhan fisik, kebutuhan keamanan, kebutuhan sosial, penghargaan diri, dan aktualisasi diri (Maslow Dalam Handoko, 1994:256).

\section{Kepuasan Kerja}

Hani Handoko (1994:82) menyatakan bahwa kepuasan adalah keadaan emosional yang menyenangkan atau tidak menyenangkan dengan mana para karyawan memandang pekerjaan mereka. Kepuasan kerja mencerminkan perasaan terhadap pekerjaannya. Ini nampak dalam sikap positif karyawan terhadap pekerjaan dan segala sesuatu yang dihadapi.

Kepuasan kerja menurut Luthans (1997: 95) adalah sikap yang dikembangkan oleh para karyawan sepanjang waktu mengenai berbagai segi pekerjaan seperti upah, gaya penyeliaan,rekan sekerja,promosi dan pekerjaan itu sendiri. Kepuasan kerja bukanlah sesuatu yang statis tetapi merupakan subyek yang dapat mempengaruhi dan memodifikasi berbagai kekuatan yang terdapat dalam individu (pegawai). Bagi banyak orang yang berpendidikan dan berkemampuan baik, salah satu tujuan bekerja adalah untuk memperoleh kepuasan kerja. Kondisi kepuasan kerja akan tercapai apabila dalam pekerjaan dapat menggerakkan motivasi yang kuat untuk mencapai kinerja yang baik.

Untuk mengetahui indikator apa saja yang mempengaruhi kepuasan kerja, menurut Luthans (1997) terdiri atas lima indikator, yaitu Pembayaran, Pekerjaan itu sendiri, Rekan kerja, Promosi pekerjaan, Kepenyeliaan (supervisi).

\section{Hipotesis}

Berdasarkan model konsep diatas, selanjutnya dapat dijabarkan ke dalam variabel penelitian agar variabel tersebut dapat diamati dan diukur. Maka dari itu perlu dijabarkan lebih lanjut kedalam bentuk hipotesis. Menurut Sugiyono (2010:93) "Hipotesis merupakan suatu jawaban sementara terhadap perumusan masalah penelitian, oleh karena itu rumusan masalah penelitian biasanya disusun dalam bentuk kalimat pertanyaan".

Sedangkan menurut Arikunto (2006:71) "Hipotesis dapat diartikan sebagai suatu jawaban yang bersifat sementara terhadap permasalahan 
penelitian, sampai terbukti melalui data yang terkumpul". Jadi hipotesis juga dapat dinyatakan sebagai jawaban teoritis terhadap rumusan masalah penelitian, belum jabawan yang empiric. Pada penelitian ini, dapat digambarkan model hipotesis sebagaimana ditunjukkan dalam gambar berikut:

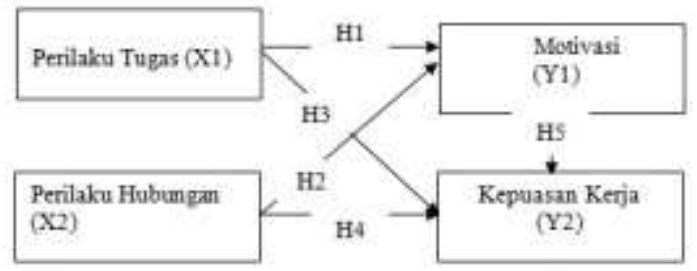

Gambar 1: Model Hipotesis

Dalam penelitian ini yang merupakan variabel independen atau bebas adalah Perilaku Tugas (X1) dan Perilaku Hubungan (X2), sedangkan yang menjadi variabel dependen atau terikat adalah Motivasi (Y1) dan Kepuasan Kerja (Y2). Berdasarkan model hipotesis yang merupakan pengembangan dari model konsep, maka perumusan hipotesis dalam penelitian ini adalah:

1. Perilaku Tugas (X1) mempunyai pengaruh signifikan terhadap Motivasi (Y1).

2. Perilaku Hubungan (X2) mempunyai pengaruh signifikan terhadap Motivasi (Y1).

3. Perilaku Tugas (X1) mempunyai pengaruh signifikan terhadap Kepuasan Kerja (Y2).

4. Perilaku Hubungan (X2) mempunyai pengaruh signifikan terhadap Kepuasan Kerja (Y2).

5. Motivasi (Y1) mempunyai pengaruh signifikan terhadap Kepuasan Kerja (Y2).

\section{METODE PENELITIAN}

\section{Jenis Penelitian}

Pendekatan dalam penelitian ini secara kesuluruhan menggunakan pendekatan kuantitatif. Penelitian kuantitatif adalah suatu pendekatan penelitian yang bersifat obyektif, mencakup pengumpulan dan analisis data kuantitatif serta menggunakan pengujian statistic. Pernyataan tersebut diungkapkan oleh Hermawan (2003). Berdasarkan obyek dan tujuan yang telah ditetapkan, maka jenis penelitian ini termasuk penelitian explanatory research (penjelasan). Sebagaimana yang dikatakan oleh Singarimbun dan Effendi (2006:5) bahwa penelitian penjelasan explanatory dapat berguna untuk menjelaskan adanya pengaruh variable-variabel yang diuji dengan menggunakan pengujian statistik. Dalam penelitian ini akan diketahui bagaimana deskripsi dari variable Perilaku Tugas (X1) dan Perilaku Hubungan (X2) berpengaruh terhadap Motivasi (Y1) dan Kepuasan Karyawan (Y2) di Universitas Brawijaya Malang.

\section{Skala Pengukuran}

Setelah ditetapkan item-item dari variabel yang ada, maka langkah selanjutnya adalah mengadakan pengukuran atas variabel-variabel tersebut, dimana untuk mengukur tanggapan responden dalam penelitian ini dipergunakan skala Likert. Menurut Sugiyono (2006:134) skala Likert digunakan untuk mengukur sikap, pendapat, dan persepsi seseorang atau sekelompok orang tentang fenomena sosial.

\section{Populasi dan Sampel}

Arikunto (2006:130) mendefinisikan "Populasi adalah keseluruhan subjek penelitian". Sedangkan sugiyono (2010:115) menyatakan "Populasi adalah wilayah generalisasi yang terdiri atas obyek/subyek yang mempunyai kualitas dan karakteristik tertentu yang ditetapkan oleh peneliti untuk dipelajari dan kemudian ditarik kesimpulan. Pada penelitian ini populasi yang digunakan adalah seluruh kasubag yang ada di lingkungan Universitas Brawijaya Malang yang berjumlah sebesar 94 orang.

\section{Sampel}

Sampel adalah sebagian atau wakil populasi yang diteliti (Arikunto, 2002). Menurut Alimul (2003) sampel merupakan bagian populasi yang akan diteliti atau sebagian jumlah dari karakteristik yang dimiliki oleh populasi. Besarnya sampel ditentukan dengan rumus dan memenuhi kriteria inklusi dan eksklusi, dimana kriteria tersebut menentukan dapat dan tidaknya sampel tersebut digunakan (Alimul, 2003).

Rumus tersebut berdasarkan pernyataan jika jumlah subyek adalah kurang dari 100 maka lebih baik diambil semua, karena jumlah sampel kurang dari 100 maka sampel yang diambil dalam penelitian ini adalah keseluruhan Kasubag yang ada di lingkungan Universitas Brawijaya Malang yaitu sejumlah 94 orang. Penentuan sampel 
dalam penelitian ini menggunakan teknik sampel Jenuh.

\section{Teknik Pengumpulan Data, Instrumen Penelitian}

Dalam suatu penelitian, data merupakan komponen penting yang sangat dibutuhkan dan data tersebut haruslah sesuai dengan kebenarannya agar mempermudah dalam menganalisis setiap permasalahan. Sumber data dalam penelitian ini yaitu:

1. Data Primer yaitu data yang diperoleh dan dikumpulkan secara langsung dari jawaban responden. Data primer pada penelitian ini didapat langsung dari lokasi penelitian dengan menyebarkan kuesioner kepada responden serta dibantu dengan wawancara.

2. Data Sekunder yaitu data yang diperoleh melalui pengumpulan dokumen-dokumen yang telah ada pada universitas. Dokumen tersebut antara lain seperti sejarah berdirinya, jumlah karyawan, gambaran umum, struktur organisasi maupun sumber tertulis lainnya yang berhubungan dengan obyek penelitian.

Untuk menguji hipotesis, diperlukan data yang benar, cermat, serta akurat karena keabsahan hasil pengujian hipotesis bergantung kepada kebenaran dan ketepatan data. Sedangkan kebenaran dan ketepatan data yang diperoleh bergantung kepada alat pengumpul data yang digunakan (instrument) serta sumber data.

Teknik pengukuran dalam instrument pada penelitian ini akan menggunakan skala likert, adapun pertimbangan digunakan angket skala likert dalam penelitian ini adalah sebagai berikut : 1. Skala Likert memiliki tingkat reliabilitas tinggi dalam pengurutkan manusia berdasarkan intensitas sikap tertentu, 2. Skala Likert sangat luwes dan fleksibel dari pada teknik pengukuran lainnya. Seperti yang dikutip Sugiyono dari buku yang ditulis S. Nasution (1987).

\section{Uji Validitas dan Reliabilitas}

Uji Validitas dan Reliabilitas diperlukan untuk melakukan pengujian terhadap item-item yang ada dalam variable yang diteliti agar kesimpulan penelitiannya tidak keliru dan tidak memberikan gambaran yang jauh berbeda dari keadaan yang sebenarnya. Pengujian validitas dan reliabilitas masing-masing variable pada penelitian ini menggunakan bantuan computer melalui program SPSS for Windows.

Cara yang dipakai dalam menguji tingkat validitas adalah dengan variabel internal, yaitu menguji apakah terdapat kesesuaian antara bagian instrumen secara keseluruhan. Untuk mengukurnya menggunakan analisis butir. Pengujian pada analisis butir yaitu dengan cara menghitung korelasi butir dengan total skor. Kesesuaian harga $r$ diperoleh dari akan dikonsultasikan dengan $r$ tabel. Butir instrumen tersebut vali jika $r_{x y}$ lebih besar dari $r$ tabel.

Pada penelitian ini untuk mencari reliabilitas instrumen menggunakan rumus alpha $\boldsymbol{\alpha}$, karena instrumen dalam penelitian ini berbentuk angket atau daftar pertanyaan yang skornya merupakan rentangan antara 1-5 dan uji validitas menggunakan item total. Indikator pengukuran reliabilitas menurut Sekaran (2000: 312) yang membagi tingkatan reliabilitas dengan kriteria sebagai berikut :

1. $0,8-1,0=$ Reliabilitas baik

2. $0,6-0,799=$ Reliabilitas diterima

3. kurang dari $0,6=$ Reliabilitas kurang baik

\section{Analisis Data}

Langkah selanjutnya setelah pengumpulan data adalah menganalisis data untuk mencari hubungan terhadap variable-variabel yang diteliti untuk membenarkan atau menyalahkan hipotesis penelitian. Analisis data merupakan bagian yang sangat penting dalam metode ilmiah, karena analisalah, data tersebut dapat diberi arti dan mana yang berguna dalam memecahkan asalah penelitian. Tujuan dari penggunaan analisis data adalah menyederhanakan data kedalam bentuk yang lebih mudah untuk dibaca dan interpretasikan sesuai dengan tujuan yang telah ditetapkan. Dalam penelitian ini, analisis data yang digunakan meluputi :

\section{Analisis Deskriptif}

Analisis deskriptif digunakan untuk menganalisa data dengan mendeskripsikan atau menggambarkan data yang telah terkumpul sebagaimana adanya tanpa bermaksud membuat kesimpulan yang berlaku untuk umum atau generalisasi (Sugiyono, 2010: 206). Dengan demikian, akan diperoleh frekuensi, presentasi dan rata-rata skor jawaban responden untuk 
masing-masing item pernyataan yang ada pada setiap variable. Setelah itu, skor yang diperoleh dari masing-masing Item variable tersebut selanjutnya dianalisis guna mengungkapkan fenomena yang terdapat pada tiap variable sesuai dengan persepsi responden.

\section{Analisis Jalur (Path Analysis)}

Beberapa asumsi yang mendasari analisis jalur (Path Analysis) menurut Riduwan, (2007) adalah sebagai berikut.

1) Hubungan antar variabel adalah bersifat linier, adaptif dan bersifat normal.

2) Hanya sistem aliran kausal ke satu arah artinya tidak ada arah kausalitas yang berbalik.

3) Variabel terikat (endogen) minimal dalam skala ukur interval atau ratio.

4) Menggunakan sample probability sampling yaitu teknik pengambilan sample untuk memberikan peluang yang sama pada setiap anggota populasi untuk dipilih menjadi anggota sampel.

5) Observed variables diukur tanpa kesalahn (instrument pengukuran valid dan reliable), artinya variabel yang diteliti dapat diobservasi secara langsung.

6) Model yang dianalisis dispesifikasikan (diidentifikasi) dengan benar berdasarkan teori-teori dan konsep-konsep yang relevan artinya model teori yang dikaji atau diuji dibangun berdasarkan kerangka teorits tertentu yang mampu menjelaskan hubungan kausalitas antar variabel yang diteliti.

\section{HASIL DAN PEMBAHASAN Karakteristik Responden}

Karakteristik responden ini dipergunakan untuk mendapatkan gambaran yang jelas mengenai karakter-karakter dari responden dalam penelitian. Setelah melakukan penelitian dan menyebarkan kuesioner kepada responden sebanyak 94 orang. Umur terbanyak responden adalah yang berumur antara $31-40$ tahun. hal ini menandakan bahwa mayoritas pegawai berada dalam usia produktif. Pada rentang usia ini, responden sudah sangat mengenal sifat pekerjaan yang menjadi tanggung jawabnya serta bangunan karir sudah mulai ditata sehingga pada rentang usia ini sangat tepat dikategorikan sebagai usia matang dalam bekerja. Jenis kelamin terbanyak responden adalah laki-laki. Hal ini menandakan bahwa tidak ada perbedaan gender pada posisi yang ditempati. Dominasi responden dengan jenis kelamin laki-laki memberikan indikasi bahwa pada sebagian besar unit bersifat outdoor, yaitu kegiatan kerja yang banyak dilakukan di luar ruangan. Jumlah terbanyak responden adalah yang telah menempuh pendidikan Sarjana. Hal ini menandakan bahwa mayoritas pegawai telah mempunyai minimal pendidikan sesuai dengan syarat dalam bekerja. Proporsi responden dengan tingkat pendidikan pascasarjana menerangkan bahwa kesempatan untuk melanjutkan ke jenjang yang lebih tinggi hingga level pascasarjana masih terbuka luas. Jumlah responden terbanyak adalah yang bekerja antara 5-10 tahun. Hal ini menandakan bahwa mayoritas pegawai mempunyai pengalaman yang cukup lama dalam bekerja. Proporsi masa kerja kurang dari 5 tahun yang hanya berjumlah 8 responden, menerangkan bahwa jabatan kasubbag di lingkungan Brawijaya adalah jabatan karir yang tidak banyak diemban oleh karyawan-karyawan muda.

\section{Distribusi Jawaban Responden}

Analisis statistik deskriptif ini dimaksudkan untuk mengetahui distribusi frekuensi jawaban responden dari hasil kuesioner yang telah disebarkan meliputi empat variabel yaitu perilaku tugas (X1), perilaku hubungan (X2), motivasi kerja (Y1), dan kepuasan kerja (Y2) di universitas brawijaya. Analisis ini bersifat memberikan makna secara deskriptif dan kecenderungan yang muncul mengenai variabel penelitian sesuai dengan hasil dari data di lapangan tanpa menarik suatu kesimpulan berarti. Dalam hal ini dasar interpretasi skor tanggapan responden pada setiap variabel penelitian adalah nilai rata-rata dan distribusi frekuensi jawaban atas setiap butir pertanyaan. Pengukuran setiap item dari masing-masing variabel menggunakan skala Likert dengan skor $1-5$.

Tabel 1. Distribusi Jawaban Perilaku Tugas (X1)

\begin{tabular}{|l|c|}
\hline \multicolumn{1}{|c|}{ Indikator } & Rata-rata \\
\hline Penyusunan tujuan (X11) & 4.21 \\
\hline Pengoranisasian (X12) & 4.21 \\
\hline Menciptakan batas waktu (X13) & 4.20 \\
\hline Pengarahan (X14) & 4.18 \\
\hline Pengendalian (X15) & 4.21 \\
\hline Variabel & 4.20 \\
\hline
\end{tabular}


Pada lima indikator perilaku tugas pimpinan, nilai rata-rata indikator yang berada di bawah nilai rata-rata variabel antara lain: pengarahan, sedangkan pada empat indikator lainnya mempunyai nilai rata-rata indikator di atas ratarata variabel. Kelemahan dari bagian pengarahan meliputi pengarahan cara pelaksanaan kerja dan penjelasan deskripsi pekerjaan. Indikator dengan nilai rata-rata tertinggi ada pada indikator penyusunan tugas, pengorganisasian dan pengendalian. Masing-masing indikator yang telah dinilai baik ini memiliki keunggukan antara lain, penetapan target hasil kerja, koordinasi pelaksanaan pekerjaan dan menerapkan hukuman.

Tabel 2. Distribusi Jawaban Perilaku Hubungan (X2)

\begin{tabular}{|l|c|}
\hline \multicolumn{1}{|c|}{ Indikator } & Rata-rata \\
\hline Penyusunan dukungan (X21) & 4.23 \\
\hline Mengkomunikasikan (X22) & 4.18 \\
\hline Memudahkan interaksi (X23) & 4.21 \\
\hline Aktif menyimak (X24) & 4.26 \\
\hline Memberikan umpan balik (X15) & 4.19 \\
\hline Variabel & 4.22 \\
\hline
\end{tabular}

Pada lima indikator perilaku hubungan pimpinan, nilai rata-rata indikator yang berada di bawah nilai rata-rata variabel antara lain: mengkomunikasikan, memudahkan interaksi dan aktif menyimak, sedangkan pada dua indikator lainnya mempunyai nilai rata-rata di atas rata-rata variabel. Kelemahan dari bagian mengkomunikasikan, memudahkan interaksi dan aktif menyimak meliputi peluang mengutarakan ide, kemudahan interaksi dengan atasan dan membantu perkembangan karir bawahan . Indikator dengan nilai rata-rata tertinggi ada pada indikator penyusunan dukungan dan aktif menyimak. Masing-masing indikator yang telah dinilai baik ini memiliki keunggulan antara lain, pemberian dukungan dan tanggap terhadap permasalahan yang terjadi.

\section{Tabel 3. Distribusi Jawaban Variabel Motivasi (Y1)}

\begin{tabular}{|l|c|}
\hline \multicolumn{1}{|c|}{ Indikator } & Rata-rata \\
\hline Kebutuhan Fisik (Y11) & 4.20 \\
\hline Kebutuhan Keamanan (Y12) & 4.24 \\
\hline Kebutuhan Sosial (Y13) & 4.26 \\
\hline Kebutuhan harga diri (Y14) & 4.23 \\
\hline Kebutuhan aktualisasi diri (Y15) & 4.27 \\
\hline Variabel & 4.24 \\
\hline
\end{tabular}

Pada lima indikator motivasi kerja karyawan , nilai rata-rata indikator yang berada di bawah nilai rata-rata variabel antara lain: kebutuhan fisik dan kebutuhan harga diri, sedangkan pada tiga indikator lainnya mempunyai nilai rata-rata di atas rata-rata variabel. Kelemahan dari kebutuhan fisik dan kebutuhan harga diri meliputi libur dan cuti sesuai ketentuan dan memberikan jaminan nama baik. Indikator dengan nilai rata-rata tertinggi ada pada indikator kebutuhan keamanan, kebutuhan sosial dan kebutuhan aktualisasi diri. Masing-masing indikator yang telah dinilai baik ini memiliki keunggulan antara lain, kondisi kerja yang aman, kesempatan berekreasi bagi karyawan pada periode tertentu serta pemberian pujian untuk perkembangan dan pertumbuhan pribadi karyawan.

Tabel 4. Distribusi Jawaban Variabel Kepuasan Kerja (Y2)

\begin{tabular}{|l|c|}
\hline \multicolumn{1}{|c|}{ Indikator } & Rata-rata \\
\hline Kepuasan pembayaran (Y21) & 4.20 \\
\hline Kepuasan terhadap pekerjaan (Y22) & 4.24 \\
\hline $\begin{array}{l}\text { Kepuasan terhadap rekan kerja } \\
\text { (Y23) }\end{array}$ & 4.19 \\
\hline Kepuasan terhadap promosi (Y24) & 4.22 \\
\hline Keuasan terhadap atasan (Y25) & 4.21 \\
\hline Variabel & 4.21 \\
\hline
\end{tabular}

Pada lima indikator kepuasan kerja pimpinan, nilai rata-rata indikator yang berada di bawah nilai rata-rata variabel antara lain: kepuasan pembayaran dan kepuasan terhadap rekan kerja, sedangkan pada tiga indikator lainnya mempunyai nilai rata-rata di atas rata-rata variabel. Kelemahan dari kepuasan pembayaran dan kepuasan terhadap rekan kerja meliputi kecukupan gaji sesuai dengan tanggung jawab dan menikmati bekerja dengan teman sendiri. Indikator dengan nilai rata-rata tertinggi ada pada indikator kepuasan terhadap pekerjaan, promosi dan atasan. Masing-masing indikator yang telah dinilai baik ini memiliki keunggulan antara lain, pekerjaan memberikan umpan balik yang baik bagi kehidupan, suka dengan atasan yang cukup memberikan dukungan dna hubungan baik dari atasan dalam memberikan arahan. 


\section{Hasil Analisis Jalur}

Pengujian hipotesis berdasarkan dari tabulasi kuisioner yang diperoleh dari jawaban responden yaitu karyawan perusahaan yang kemudian dianalisis dengan analisis jalur (path analysis). Analisis jalur ini digunakan untuk menganalisis hubungan sebab akibat yang terjadi pada regresi berganda jika variabel bebasnya mempengaruhi variabel tergantung tidak hanya secara langsung, tetapi juga secara tidak langsung, dimana digunakan untuk menguji hubungan antara kompensasi terhadap Perilaku Hubungan, kompensasi terhadap kinerja, dan Perilaku Hubungan terhadap kinerja. Hasil ini menjelaskan bahwa keragaman kepuasan karyawan dapat dijelaskan secara langsung oleh motivasi kerja karyawan. Pendugaan terhadap seluruh koefisien jalur yang dimodelkan pada penelitian ini dapat diringkas pada Tabel.

Tabel 5. Ringkasan Koefisien Jalur

\begin{tabular}{|c|c|c|c|}
\hline $\begin{array}{c}\text { Variabel } \\
\text { Independen }\end{array}$ & $\begin{array}{c}\text { Variabel } \\
\text { Dependen }\end{array}$ & Beta & $\begin{array}{c}p \text { - } \\
\text { value }\end{array}$ \\
\hline $\begin{array}{c}\text { Perilaku } \\
\text { tugas }\end{array}$ & $\begin{array}{c}\text { Motivasi } \\
\text { kerja } \\
\text { karyawan }\end{array}$ & 0.432 & 0.000 \\
\hline $\begin{array}{c}\text { Perilaku } \\
\text { hubungan } \\
\text { kerja } \\
\text { karyawan }\end{array}$ & 0.556 & 0.000 \\
\hline $\begin{array}{c}\text { Perilaku } \\
\text { tugas }\end{array}$ & $\begin{array}{c}\text { Kepuasan } \\
\text { karyawan }\end{array}$ & 0.260 & 0.006 \\
\hline $\begin{array}{c}\text { Perilaku } \\
\text { hubungan }\end{array}$ & $\begin{array}{c}\text { Kepuasan } \\
\text { karyawan }\end{array}$ & 0.456 & 0.000 \\
\hline $\begin{array}{c}\text { Motivasi } \\
\text { kerja } \\
\text { karyawan }\end{array}$ & $\begin{array}{c}\text { Kepuasan } \\
\text { karyawan }\end{array}$ & 0.277 & 0.005 \\
\hline
\end{tabular}

Sumber: Data Primer Diolah, 2013

Tabel di atas menjelaskan bahwa dari kelima jalur pada model hipotesis seluruh jalur adalah signifikan. Peran dominan terhadap motivasi kerja karyawan bersumber dari perilaku hubungan, sedangkan terhadap kepuasan karyawan pengaruh dominan juga bersumber dari perilaku hubungan. Secara khusus kedua jalur dominan ini menjadi menarik karena menjadi penentu tingginya kepuasan kerja karyawan. Untuk lebih jelasnya hasil analisis jalur secara keseluruhan dapat disajikan pada Gambar

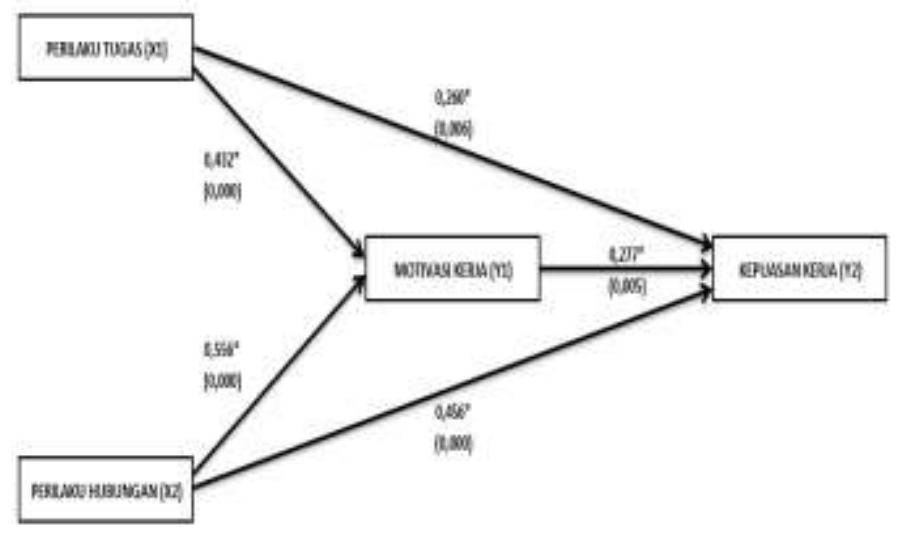

Gambar 2.

Hasil Analisis Jalur

Pada Gambar dapat dijelaskan bahwa faktor penentu motivasi kerja bersumber dari kepemimpinan perilaku tugas (X1) dan perilaku hubungan (X2). Kepemimpinan dari perilaku hubungan dominan dalam meningkatkan motivasi kerja karyawan. Faktor penentu kepuasan kerja karyawan bersumber dari kepemimpinan perilaku tugas (X1), perilaku hubungan (X2) dan motivasi kerja (Y1). Kepemimpinan dari perilaku hubungan dominan dalam meningkatkan kepuasan kerja karyawan.

Ketetapan model hipotesis dari data penelitian diukur dari hubungan dua koefisien determinan $\left(\mathrm{R}^{2}\right)$ di kedua persamaan. Pada persamaan pertama diperoleh nilai $\mathrm{R}^{2}$ sebesar 0,966 dan $\mathrm{R}^{2}{ }_{2}$ sebesar 0,971 pada persamaan kedua.

Hasil ketetapan model adalah :

$$
\begin{aligned}
\text { R2model } & =1-\left(1-\mathrm{R}^{2}{ }_{1}\right)\left(1-\mathrm{R}^{2}{ }_{2}\right) \\
& =1-(1-0,966)(1-0,971) \\
& =1-0,000986 \\
& =0,9990 \text { atau } 99,90 \%
\end{aligned}
$$

Hasil perhitungan ketetapan model sebesar 99,9\% menerangkan bahwa kontribusi model untuk menjelaskan hubungan struktural dari keempat variabel yang diteliti adalah sebesar 99,9\% dan sisanya dijelaskan oleh variabel lain yang tidak terlibat dalam model.

\section{Pembahasan}

Hasil permodelan menjelaskan bahwa ada hubungan struktural antara kepemimpinan, motivasi kerja dan kepuasan kerja karyawan. Kepuasan kerja karyawan di level kasubag dapat 
dijelaskan oleh tingginya motivasi kerja dan pola kepemimpinan yang diterapkan kabag di masingmasing unit. Berdasarkan besar koefisien jalur yang diperoleh dari hasil analisis, kepemimpinan dengan menekankan perilaku hubungan adalah lebih efektif untuk memperkuat motivasi kerja dibandingkan dengan perilaku tugas. Pada tingkat kasubag, pemahaman akan job desctiption pada setiap tugas telah diketahui dengan baik. Pengalaman saat meniti karir di tingkat staff memberika peluang besar untuk lebih mengenal dengan lebih baik akan pekerjaan yang harus dilakukan.

\section{Pengaruh Variabel Perilaku Tugas terhadap Motivasi}

Hasil analisis menerangkan bahwa terdapat pengaruh positif yang nyata antara perilaku tugas terhadap motivasi kerja. Hal ini menandakan bahwa perilaku tugas pimpinan terutama dalam penelitian ini Kasubag di Lingkungan Universitas Brawijaya memberikan nilai positif bagi staf untuk menjadi lebih termotivasi dalam bekerja. Hal ini didukung oleh teorinya Susilo Martoyo (2007:155) mengatakan bahwa tidak akan ada motivasi jika tidak dirasakan dengan adanya kebutuhan. Pekerjaan yang dilakukan oleh seorang atasan dalam memberikan inspirasi, semangat dan dorongan kepada orang lain dalam hal ini adalah karyawan, untuk mengambil tindakan-tindakan. Pemberian motivasi dengan gaya kepemimpinan ini bertujuan untuk menggiatkan karyawan agar bersemangat dan dapat mencapai hasil sebagaimana yang dikehendaki. Hasil Penelitian ini mendukung hasil penelitian Maisardana (2006) yang mengatakan bahwa gaya kepemimpinan berpengaruh secara signifikan terhadap motivasi kerja.

Kelemahan pada penerapan kepemimpinan dari aspek perilaku tugas yang teramati dari hasil penelitian antara lain : pengarahan cara pelaksanaan kerja dan penjelasan deskripsi pekerjaan. Selain kelemahan, terdapat beberapa keunggulan yang ada dalam perilaku tugas antara lain : penetapan target hasil kerja, koordinasi pelaksanaan pekerjaan dan menerapkan hukuman. Hal-hal positif dalam penerapan kepemimpinan dari perlaku tugas akan mendukung terbentuknya motivasi kerja yang tinggi. Mengukur adanya motivasi yang kuat di kalangan kasubag bisa diindikasikan oleh beberapa hal antara lain : kondisi kerja yang aman, kesempatan berekreasi bagi karyawan pada periode tertentu serta pemberian pujian untuk perkembangan dan pertumbuhan pribadi karyawan. Akan tetapi masih ada beberapa hal lain yang perlu diperhatikan oleh pihak manajemen universitas Brawijaya karena dinilai di kalangan kasubag beberapa hal berikut perlu dievaluasi dan ditingkatkan seperti libur dan cuti sesuai ketentuan dan memberikan jaminan nama baik.

\section{Pengaruh Variabel Perilaku Hubungan terhadap Motivasi Kerja}

Hasil analisis menerangkan bahwa terdapat pengaruh menyatakan terdapat pengaruh positif yang nyata antara Perilaku Hubungan terhadap Motivasi Kerja. Hal ini menandakan bahwa perilaku hubungan pimpinan, terutama dalam penelitian ini Kasubag di Lingkungan Universitas Brawijaya memberikan nilai positif kepada stafnya untuk menjadi lebih termotivasi dalam bekerja. Menurut Thoha (2007:64) perilaku hubungan merupakan titik pusat dari konsep kepemimpinan situasional. Perilaku hubungan adalah suatu perilaku seorang pemimpin untuk mengatur dan merumuskan peranan-peranan anggota-anggota kelompok atau para pengikut; menerangkan kegiatan yang harus dikerjakan oleh masing-masing anggota, kapan dilakukan, dimana melaksanakannya dan bagaimana tugastugas itu harus dicapai. Hasil Penelitian ini mendukung hasil penelitian Maisardana (2006) yang mengatakan bahwa Gaya kepemimpinan berpengaruh secara signifikan terhadap motivasi kerja.

Kelemahan pada penerapan kepemimpinan dari aspek perilaku hubungan yang teramati dari hasil penelitian antara lain : peluang mengutarakan ide, kemudahan interaksi dengan atasan dan membantu perkembangan karir bawahan. Selain kelemahan, terdapat beberapa keunggulan yang ada dalam perilaku tugas antara lain : pemberian dukungan dan tanggap terhadap permasalahan yang terjadi. Kepemimpinan dengan menekankan aspek perilaku hubungan adalah lebih dianjurkan agar motivasi kerja karyawan bisa tetap terjaga. Motivasi kerja yang tinggi dapat terukur dari persepsi karyawan bahwa kondisi kerja saat ini adalah aman, pada 
periode tertentu karyawan dan keluarganya mendapatkan kesempatan berekreasi dan atasan memberikan pujian untuk perkembangan dan pertumbuhan pribadi karyawan.

\section{Pengaruh Variabel Perilaku Tugas terhadap Kepuasan Kerja}

Hasil analisis menerangkan bahwa terdapat pengaruh positif yang nyata antara perilaku tugas terhadap kepuasan kerja. Artinya perilaku tugas pimpinan memberikan kepuasan kerja kepada stafnya. Penelitian ini mendukung penelitian Satriyo (1997) juga menghasilkan kesimpulan yang mendukung penelitian ini yakni bahwa perilaku pemimpin manajerial berpengaruh secara signifikan terhadap tingkat iklim organisasi dan secara bersama-sama perilaku pemimpin manajerial dan tingkat iklim organisasi berpengaruh secara signifikan terhadap tingkat kinerja kelompok serta kepuasan kerja.

Kelemahan pada penerapan kepemimpinan dari aspek perilaku tugas yang teramati dari hasil penelitian antara lain : pengarahan cara pelaksanaan kerja dan penjelasan deskripsi pekerjaan. Selain kelemahan, terdapat beberapa keunggulan yang ada dalam perilaku tugas antara lain : penetapan target hasil kerja, koordinasi pelaksanaan pekerjaan dan menerapkan hukuman. Kepuasan kerja mempunyai kelemahan dan kelebihan. Kelemahan kepuasan kerja yang dialami kalangan kasubag dari hasil penelitian antara lain : kecukupan gaji sesuai dengan tanggung jawab dan menikmati bekerja dengan teman sendiri. Selain kelemahan, terdapat beberapa keunggulan untuk memacu rasa puas dalam bekerja antara lain : pekerjaan memberikan umpan balik yang baik bagi kehidupan, suka dengan atasan yang cukup memberikan dukungan dan hubungan baik dari atasan dalam memberikan arahan. Unit yang berbeda akan mempunyai tantangan dan persoalan tanggungjawab kerja yang berbeda pula, sehingga tuntutan untuk mengevaluasi proporsi upah atau pendapatan dari unit yang berbeda seharusnya bisa segera dilakukan.

\section{Pengaruh Variabel Perilaku Hubungan terhadap Kepuasan Kerja}

Hasil analisis menerangkan bahwa terdapat pengaruh menyatakan bahwa terdapat pengaruh positif yang nyata antara perilaku hubungan terhadap motivasi kerja. Artinya perilaku hubungan pimpinan memberikan kepuasan kerja kepada stafnya. Penelitian ini juga di dukung penelitian Satriyo (1997) juga menghasilkan kesimpulan yang mendukung penelitian ini yakni bahwa perilaku pemimpin manajerial berpengaruh secara signifikan terhadap tingkat iklim organisasi dan secara bersama-sama perilaku pemimpin manajerial dan tingkat iklim organisasi berpengaruh secara signifikan terhadap tingkat kinerja kelompok serta kepuasan kerja.

Kelemahan pada penerapan kepemimpinan dari aspek perilaku hubungan yang teramati dari hasil penelitian antara lain : peluang mengutarakan ide, kemudahan interaksi dengan atasan dan membantu perkembangan karir bawahan. Selain kelemahan, terdapat beberapa keunggulan yang ada dalam perilaku tugas antara lain : pemberian dukungan dan tanggap terhadap permasalahan yang terjadi. Rasa puas dalam bekerja telah tampak dari beberapa hal positif yang terserap dari hasil penelitian. Beberapa keunggulan untuk memacu rasa puas dalam bekerja antara lain : pekerjaan memberikan umpan balik yang baik bagi kehidupan, suka dengan atasan yang cukup memberikan dukungan dan hubungan baik dari atasan dalam memberikan arahan.

\section{Pengaruh Variabel Motivasi terhadap Kepuasan Kerja}

Hasil analisis menerangkan bahwa terdapat pengaruh menyatakan bahwa terdapat pengaruh positif yang nyata antara motivasi terhadap kepuasan kerja. Hasil penelitian ini membuktikan bahwa motivasi kerja berpengaruh positif dan signifikan terhadap kepuasan kerja karyawan, artinya bahwa motivasi kerja memang sangat diperlukan oleh seorang karyawan untuk dapat mencapai suatu kepuasan kerja yang tinggi meskipun menurut sifatnya kepuasan kerja itu sendiri besarannya sangat relatif atau berbeda antara satu orang dengan orang lainnya. Tetapi secara keseluruhan, para responden menyatakan bahwa selama bekerja di perusahaan mereka menyatakan merasa puas atas motivasi kerja yang selama ini diberikan oleh manajemen kepada para karyawan perusahaan. 
Pada bagian motivasi kerja, kelemahan motivasi yang dialami kalangan kasubag dari hasil penelitian antara lain : libur dan cuti sesuai ketentuan dan memberikan jaminan nama baik. Selain kelemahan, terdapat beberapa keunggulan untuk memacu motivasi antara lain : kondisi kerja yang aman, kesempatan berekreasi bari karyawan pada periode tertentu serta pemberian pujian untuk perkembangan dan pertumbuhan pribadi karyawan. Kepuasan kerja mempunyai kelemahan dan kelebihan. Kelemahan kepuasan kerja yang dialami kalangan kasubag dari hasil penelitian antara lain : kecukupan gaji sesuai dengan tanggung jawab dan menikmati bekerja dengan teman sendiri. Selain kelemahan, terdapat beberapa keunggulan untuk memacu rasa puas dalam bekerja antara lain : pekerjaan memberikan umpan balik yang baik bagi kehidupan, suka dengan atasan yang cukup memberikan dukungan dan hubungan baik dari atasan dalam memberikan arahan.

\section{KESIMPULAN DAN SARAN Kesimpulan}

Dari hasil analisis data yang dilakukan baik menggunakan analisis deskriptif maupun analisis jalur, maka dapat disimpulkan beberapa hal diantaranya:

1. Kepemimpinan dengan perilaku tugas yang tepat akan dapat meningkatkan motivasi.

2. Kepemimpinan dengan perilaku hubungan yang tepat akan dapat meningkatkan motivasi.

3. Kepemimpinan dengan perilaku tugas yang tepat akan dapat meningkatkan kepuasan kerja karyawan.

4. Kepemimpinan dengan perilaku hubungan yang tepat akan dapat meningkatkan kepuasan kerja karyawan.

5. Motivasi kerja yang tinggi akan meningkatkan kepuasan kerja karyawan.

\section{Saran-saran}

Dengan melihat gaya kepemimpinan yang diwakili oleh variabel perilaku tugas (X1) dan perilaku hubungan (X2) terhadap motivasi (Y1) dan kepuasan kerja (Y2) di lingkungan Universitas Brawijaya Malang, maka dikemukakan beberapa saran yang diharapkan dapat menjadi bahan pertimbangan untuk langkah-langkah selanjutnya, diantaranya:
Berdasarkan kesimpulan di atas, maka penulis mencoba mengemukakan beberapa saran yang dapat bermanfaat bagi pihak Universitas Brawijaya dalam meningkatkan disiplin karyawannya, yaitu:

1. Kasubag dirasa perlu untuk mengadakan sesi sharing atau diskusi secara berkelanjutan dengan Karyawannya. Hal ini sebagai upaya nyata dalam meningkatkan dan membina hubungan dengan karyawan. Dengan adanya hal ini diharapkan karyawan akan lebih nyaman dalam bekerja, yang secara otomatis akan berpengaruh terhadap kinerja karyawan. Selain itu, hasil dari diskusi ini tentunya akan berpengaruh terhadap peran pimpinan yang besar dalam pembuatan keputusan, sehingga pimpinan mampu membuat keputusan yang lebih bijak dan sesuai dengan kebutuhan dan kepentingan organisasi.

2. Pemberian reward and punishment secara jelas kepada karyawan. Penerapan hal ini bagi karyawan akan mampu untuk terus mempertahankan kinerjanya, bahkan berlomba-lomba untuk selalu meningkatkan kinerja mereka. Selain itu, dengan adanya pemberian penghargaan dan hukuman maka hal ini bisa diartikan juga sebagai tindakan preventif agar kinerja yang kurang baik dapat diminimalisir.

3. Peraturan yang ada harus diperjelas dan dipertegas sehingga kepuasan kerja karyawan benar-benar akan semakin meningkat. Untuk itu Kasubag di Lingkungan Universitas Brawijaya harus benar-benar terfokus dan mensosialisasikan hal ini kepada karyawan secara optimal agar karyawan mengetahui secara mendalam job deksripsinya yang berlaku di Universitas Brawijaya.

4. Untuk mencegah terjadi pemborosan dalam penggunaan inventaris kantor, pihak Kasubag harus memberikan bimbingan dan arahan kepada karyawan agar mereka dapat menggunakan inventaris kantor secara efektif dan efisien. 
5. Berkaitan dengan dinamika organisasi, maka setiap Kasubag Universitas sebaiknya melakukan evaluasi berkala terhadap gaya kepemimpinan yang diterapkan. Kepemimpinan yang tepat adalah salah satu kebutuhan untuk mengefektifkan organisasi, karena gaya kepemimpinan juga dapat menjadi faktor terjalinnya komunikasi organisasi yang konstruktif dan produktif di lingkungan Unviversitas Brawijaya. Hasil permodelan menganjurkan agar kepemimpinan lebih banyak memasukkan unsur perilaku hubungan.

6. Untuk penelitian selanjutnya terhadap disiplin karyawan khususnya pada Kasubag, dikomendasikan untuk mengkaji faktor lain selain gaya kepemimpinan dan motivasi agar kepuasan kerja karyawan bisa lebih ditingkatkan lagi, seperti kompensasi dan penggunaan teknologi.

\section{DAFTAR PUSTAKA}

Arikunto, Suharsimi. (2006). Prosedur Penelitian : Suatu Pendekatan Praktik (Revisi VI). Jakarta : Rineka Cipta.

Bass, B.M., 1990. From Transactional to transformational Leadership. Organizational Dyinamics. Vol.18. No.3. 9-31.

Cardoso Gomes, Faustino. (1995). Manajemen Sumber Daya Manusia. Andi Offset, Yogyakarta.

Cooper, D.R dan Emory, C.W. 1999. Metode Penelitian Bisnis. Jilid II. Alih Bahasa : Seotjipto, W dan Wikarya, U.Erlannga. Jakarta.

Davis, Keith, \& Jhon W. Newstrom, 2000. Perilaku Dalam Organisasi, Edisi Ketujuh, Alih Bahasa Agus Darma, Jakarta: Erlangga

Dessler, G. (1998) Manajemen Sumber Daya Manusia. Jilid 2. Edisi Bahasa. Indonesia. PT Prenhallindo. Jakarta.

Djanaid, Djanalis. 2004. Kepemimpinan Eksekutif: Teori dan Praktek. Malang:
Univ. Brawijaya.

Gibson, J.L., Ivancevich, J.M., dan Donelly, J.Jr. (1984). Organisasi dan Manajemen: Perilaku, Struktur, dan Proses. Edisi Keempat. Jakarta: Penerbit Erlangga.

Handoko, T. Tani. 1994. Dasar- Dasar Manajemen Produksi dan Operasi. Penerbit BPFE, Yogyakarta

Hasibuan. 2003. Organisasi dan motivasi dasar peningkatan produktivitas. Jakarta: Bumi Aksara.

Hersey, P dan Blanchard K.H., 1969, "Life Cycle Theory of Leadership", Training and Development Journal, 23(2), 26-34.

Hersey, P dan Blanchard K., 2004. Teori dan Praktek Kepemimpinan, Rineka Cipta.

Kartono, Kartini, 2002, Pemimpin dan Kepemimpinan,(Apakah Pemimpin Abnormal itu ?), PT. Raja Grafindo Persada, Jakarta.

Lastiar, 2008. Pengaruh Gaya Kepemimpinan Terhadap Motivasi Kerja Pegawai Pada PT. Indosat, Tbk. Divisi Regional Wilayah Barat Medan.

Luthans, F. (1997), Organization Behavior. New York: McGraw Hill International

Maisardana, 2006. Pengaruh Gaya Kepemimpinan Terhadap Motivasi Kerja Pegawai Pada PT. Bank SUMUT Cabang Stabat.

Mangkunegara, Prabu. 2006. Evaluasi Kinerja SDM. Jakarta: Bumi Aksara

Mangkunegara, Prabu. 2006. Evaluasi Kinrja Sumber Daya Manusia. Jakarta: Refika Aditama

Martoyo, S. (2007), Manajemen Sumber Daya Manusia, BPFE, Yogyakarta.

Nawawi, Hadari, 2003 Kepemimpinan Mengektifkan Organisasi, Gadjah Mada University Press, Jakarta.

Nazir. 2009. Metode Penelitian. Ghalia Indonesia. Jakarta.

Nurlina, Lilis. 2004. Pengaruh Perilaku Kepemimpinan Orientasi Prestasi 
Terhadap Keberlanjutan Usaha Abggota Koperasi. Skripsi. Sumedang: Fakultas Peternakan Universitas Padjadjaran,

Prasojo, Mahdi. 2007. Pengaruh Gaya Kepemimpinan Terhadap Prestasi Kerja Karyawan (Studi pada Karyawan Rumah Makan Ayam Bakar Wong Solodi Malang), Malang: Universitas Negeri Malang (FEUM).

Ranupandjojo, Heidjrachman dan Husnan, Suad. 1990. Manajemen Personalia. Yogyakarta: BPFE.

Robbins, P. Stephen. (2002). Perilaku Organisasi. Jakarta: Prenhalindo

Robbins dan Judge. 2007. Perilaku Organisasi, Edisi Duabelas, Penerbit Salemba Empat: Jakarta.

Saifuddin, Azwar. 2000. Sikap Manusia Teori Dan Pengukurannya. Pustaka Pelajar. Yogyakarta.

Sarwono, Jonathan. (2006). Analisis Jalur Untuk Riset Bisnis Dengan SPSS. Penerbit Andi. Yogyakarta.

Schein, H Edgar. 1992. Organizational Culture and Leadership, Second Edtion, Jossey Bass Publishers, San Francisco

Sekaran, Uma. (1992). Research Methods for Business : A Skill-Building Approach. John Wiley \& Sons, Inc. New York.

Siagian Sondang, 2003, Teori dan Praktek Kepemimpinan, Penerbit Rineka Cipta Jakarta.

Singarimbun, M dan Efendy, S. 1995. Metode Penelitian Survey. Edisi Revisi. Bumi Aksara. Jakarta.

Solimun, 2002. Multivariate Analysis Structural Equation Modeling (SEM) Lisrel dan Amos. Universitas Negeri Malang.

Sopiah dan Sangadji. 2010. Metode Penelitian. Penerbit Andi. Malang.

Sugiyono. 2010. Metode Penelitian Pendidikan: Pendekatan Kuantitatif, Kualitatif, dan $R \& D$. Bandung: Alfabeta.
Sunarsih. (2001). Kepemimpinan Transformasional Dalam Era Perubahan Organisasi. Jurnal Managemen dan Bisnis. Vol 5 No.2. Desember 2001 : 106-116.

Suprihanto, John. (2003). Perilaku Organisasional. Yogyakarta. Sekolah Tinggi Ilmu Ekonomi. YPKN.

Thoha, Miftah, 1995. Kepemimpinan dalam Manajemen Suatu Pendekatan Perilaku. Jakarta. PT Raja Grafindo Persada,

Winardi, 2000, Kepemimpinan dalam Manajemen, Rineka Cipta, Jakarta. 